\title{
Impact of Hydropower Dam Development on River Ecosystems: Ecopath Model Application on the Red River in China as an Example
}

\author{
Xu-Xi Wang', ${ }^{1,2}$ Li Peng, ${ }^{1,2 *}$, Chun-Jiang Su${ }^{1}$, Gen-Wei Cheng ${ }^{1}$ \\ ${ }^{1}$ Institute of Mountain Hazards and Environment, Chinese Academy of Sciences, Chengdu 610041, China \\ ${ }^{2}$ State Key Laboratory of Simulation and Regulation of Water Cycle in River Basin, \\ China Institute of Water Resources and Hydropower Research, \\ Beijing 100038, China
}

Received: 11 April 2017

Accepted: 15 May 2017

\begin{abstract}
In order to reveal the influence of hydropower development on river ecology, we selected a number of research sites, including a natural channel (NC), a channel reservoir (CR), and a channel below the dam (CB) of a certain dam-type hydropower station on the Red River in China. We used the Ecopath model to analyze the differences in structures and energy characteristics of the three ecosystems. As indicated from the results, the energy flow in the three ecosystems of NC, CR, and CB mainly flows between trophic levels I and IV, and the overall transfer efficiencies of the three ecosystems are characterized by $\mathrm{CR}<\mathrm{NC}<\mathrm{CB}$. The output of primary producers in the three ecosystems are, respectively, $852 \mathrm{t} \cdot \mathrm{km}^{-2} \cdot \mathrm{y}^{-1}, 3780 \mathrm{t} \cdot \mathrm{km}^{-2} \cdot \mathrm{y}^{-1}$, and $1842.3 \mathrm{t} \cdot \mathrm{km}^{-2} \cdot \mathrm{y}^{-1}$, and the recycling flows into the detritus are $49.37 \%, 48.46 \%$, and $79.79 \%$ respectively. There are two major trophic transfer paths in the three ecosystem food webs, namely the detrital food chain and the grazing food chain. Through the comparison and analysis of the overall characteristics of the system, we found that the indicators reflecting system maturity - including total primary production/total respiration (TPP/TR), connectance index (CI), system omnivory index (SOI), Finn's cycling index (FCI), and Finn's mean path length (FML) - indicate that the maturity of the ecosystem of $\mathrm{CB}$ is lower than that of $\mathrm{NC}$, and is much lower than that of $\mathrm{CR}$. The results show that the ecosystems of $\mathrm{CR}, \mathrm{NC}$, and $\mathrm{CB}$, respectively, are in basically mature, immature, and unstable "young" states. This trophic model analysis also provides a new research perspective on the studies of the influence of hydropower development on riverine ecology.
\end{abstract}

Keywords: hydropower development, Ecopath, trophic level, river ecosystems, Red River

\section{Introduction}

In the past several decades, China has been in the process of rapid industrialization, urbanization, and

*e-mail: pengli@imde.ac.cn modernization. Inevitably, a huge energy demand accompanies the process [1]. The development of electricity generation in china has been rapid. Yearly electricity generation reached 351.4 TWh in 1983 and $5,347.4 \mathrm{TWh}$ in 2013 , with a 15 -fold increase in 30 years [2]. Owing to the adjustment of industrial structure, the transformation and upgrading of industry and the 
construction of an ecological environment, etc., China has attached great importance to renewable energy development aimed at reducing its dependence on coal and other fossil fuels [2-3]. So the structure of electricity generation also has seen significant changes in China. Due to its huge territory and large physiographic diversity, China has the largest exploitable hydropower potential in the world [4]. As the most mature sustainable technology and one of the most flexibility sustainable energy sources, hydropower has been actively pursued in China and has made significant progress in recent years [5-6]. Its gross installed hydropower capacity reached $320 \mathrm{GW}$ by the end of 2015, exceeding the cumulative values of the USA, Brazil, and Canada, which ranks just after China in terms of hydropower installed capacity.

Though hydropower projects are considered relatively clean in terms of environmental emissions, they actually cause direct and indirect detrimental impacts on river systems by altering the water flow patterns and restructuring of natural habitats [7-9]. This means hydropower projects may be unsustainable from the environmental perspective if no protective measures are taken to conserve the ecosystems. Significant ecological changes have happened after damming. Hydropower dam development has disrupted hydrological continuity and artificially altered the original material, energy, chemistry, and biological environment, directly affecting the biogeochemical behavior of elements in the river [1012]. Therefore, species composition, habitat distribution, and corresponding ecological functions of the river ecosystems are changed, leading to the degradation of the river's ecosystems [13-14]. Dams fragment river systems, causing significant effects throughout the river systems (including aquatic and terrestrial ecosystems) on different levels [15]. These effecting levels are monomer, group, assemblages, and entire environments in a generic depiction, while it refers to the individual, population, community, and ecosystem in the biological realm [16]. And the related factors of these ways are river morphology, hydrology, and habitat as well as related biota within the river system [17]. An important river in southwest China, the Red River, flows primarily through three countries: China, Vietnam, and Laos. Since the turn of the century, the cascade hydropower development of Yuanjiang in the Red River basin has been listed as a key national development project by the Chinese government. While creating economic and environmental benefits, the upstream cascade hydropower development of the Red River also has multiple negative impacts on the river and downstream ecosystem, particularly the decline of biodiversity [18-19]. Therefore, a proper understanding of the influences of the development on the ecological environment is vital for evaluating the benefits, protecting river ecology, and guiding the rational utilization of crossborder water resources in the basin.

The Ecopath model is a convenient tool for studying the structure of ecosystems, especially aquatic [20]. Based on the principle of energy balance, the model uses a system of linear homogeneous equations to describe the flow processes of biological compositions and energy within the ecosystem, and quantifies some ecological parameters such as biomass (B), production/biomass ratio (P/B), consumption/biomass ratio (C/B), trophic level (TL), and ecotrophic efficiency (EE). Ecopath is the most globally applied tool for modeling marine and aquatic ecosystems, with more than 400 models published to date [21]. It is able to address many of the marine policy issues faced by managers, such as natural variability and monitoring,

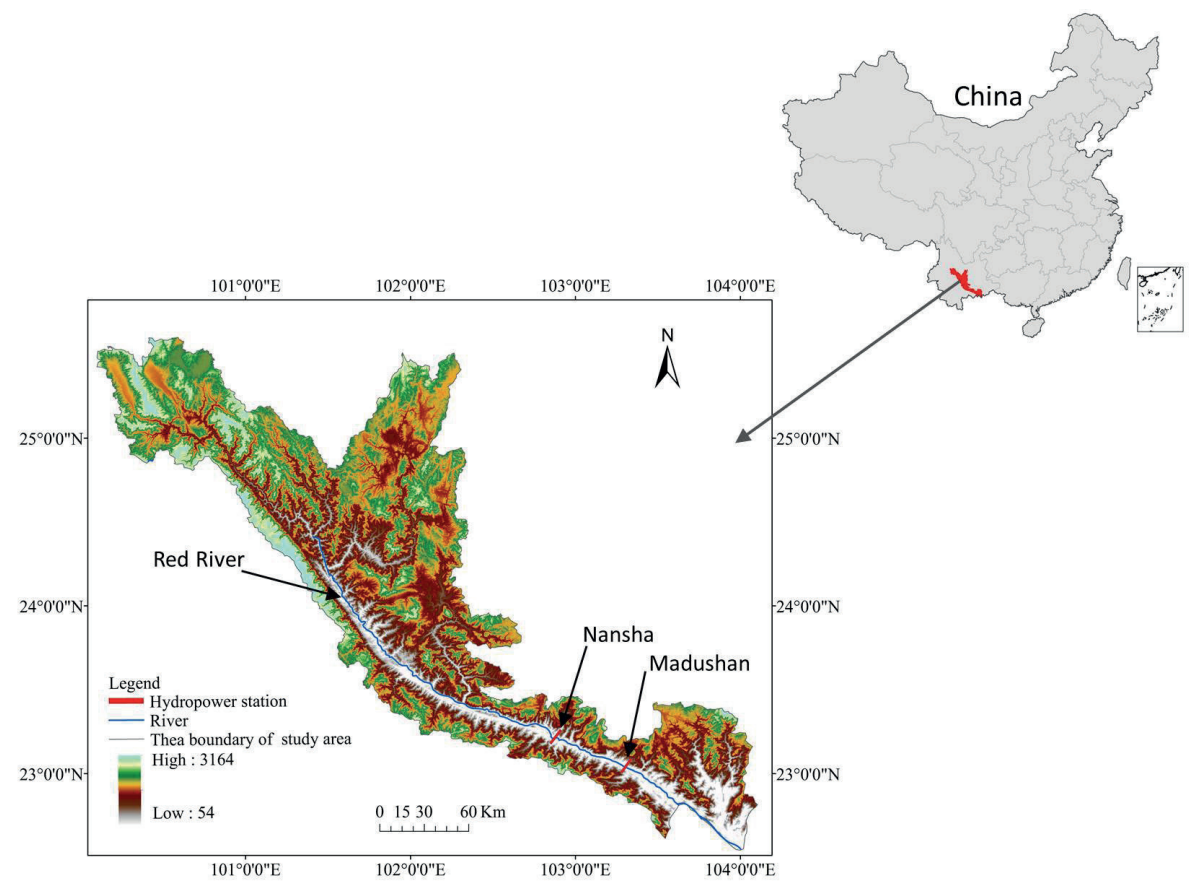

Fig. 1. Location of Red River Basin. 
management measures, ecosystem goods and services, "Good Environmental Status" targets for the EU Marine Strategy Framework Directive, and environmental change and climate adaptation [22-23]. Firstly, this study attempts to use the Ecopath model to study the overall ecological characteristics of ecosystems of the Red River, focusing on three research sites: a natural channel (NC), channel reservoir (CR), and channel below the dam (CB). We look at the trophic level range and energy transfer efficiency of each functional group and determine the proportions of energy in primary producers and detritus. Moreover, this study evaluates and compares the stability degree and development status of each ecosystem. Ultimately, the influences of the dam-type hydropower development on the river ecosystems are comprehensively assessed so as to provide robust theoretical guidance for followup ecological regulation of the cascade hydropower development of the Red River.

\section{Materials and Methods}

\section{Study Area}

As one of the main rivers between China and Vietnam, the Red River originates in Weishan County, Dali Bai Autonomous Prefecture, Yunnan Province (Fig. 1). With a total length of about $1,200 \mathrm{~km}$, the river drop is $2,580 \mathrm{~m}$ within a catchment area of $136,800 \mathrm{~km}^{2}$. It flows from the frontier in Shankou County into Vietnam, emptying into the Beibu Gulf in the Red River Delta. In China, the total length of the Red River basin is $692 \mathrm{~km}$, and the river drop is $2,510 \mathrm{~m}$, within a catchment area of $76,276 \mathrm{~km}^{2}$, which accounts for $55.76 \%$ of the whole basin.

The vast majority of the basin belongs to mountainous or semi-mountainous areas, while the plains account for less than $5 \%$ of the catchment area. With an average annual temperature of $15-22^{\circ} \mathrm{C}$, the basin is dominated by a subtropical monsoon climate. The rainy season occurs between May and October with rainfall during this time accounting for $85 \%$ of annual precipitation.

In recent years, the Chinese government has planned an 11-grade cascade hydropower development program for reaches of the Red River, taking into account factors such as flood control in major cities and towns, the demands of agricultural irrigation, and the water supply along the river banks and the shipping requirements for the middle and lower reaches. Presently, Nansha and Madushan hydropower stations have installed grid-connected power, while other hydropower stations are still in the preparatory stage. Madushan hydropower station, with a total reservoir capacity of 551 million $\mathrm{m}^{3}$ and a regulating reservoir capacity of 260 million $\mathrm{m}^{3}$, is a dam-type development hydropower project with incomplete annual regulating performance. The installed capacity of the hydropower station is $288 \mathrm{MW}$ and the designed annual generating capacity is 1.314 billion $\mathrm{kWh}$. The hydropower station achieved the closure of the river in December 2008, and officially carried out impounding at the end of December 2010. The geographical location of the dam at Madushan hydropower station includes reaches divided into three sections, namely NC (the upstream natural channel above the Nansha Reservoir area), CR (the Madushan Reservoir area) and CB (the downstream channel under Madushan Dam).

\section{The Research Process}

In order to reveal the influence of hydropower development on river ecology, we selected a number of research sites, including $\mathrm{NC}, \mathrm{CR}$, and $\mathrm{CB}$ of a certain dam-type hydropower station on the Red River in China and use the Ecopath model to analyze the differences in structures and energy characteristics of the three ecosystems. This specific research process is consistent with Fig. 2.

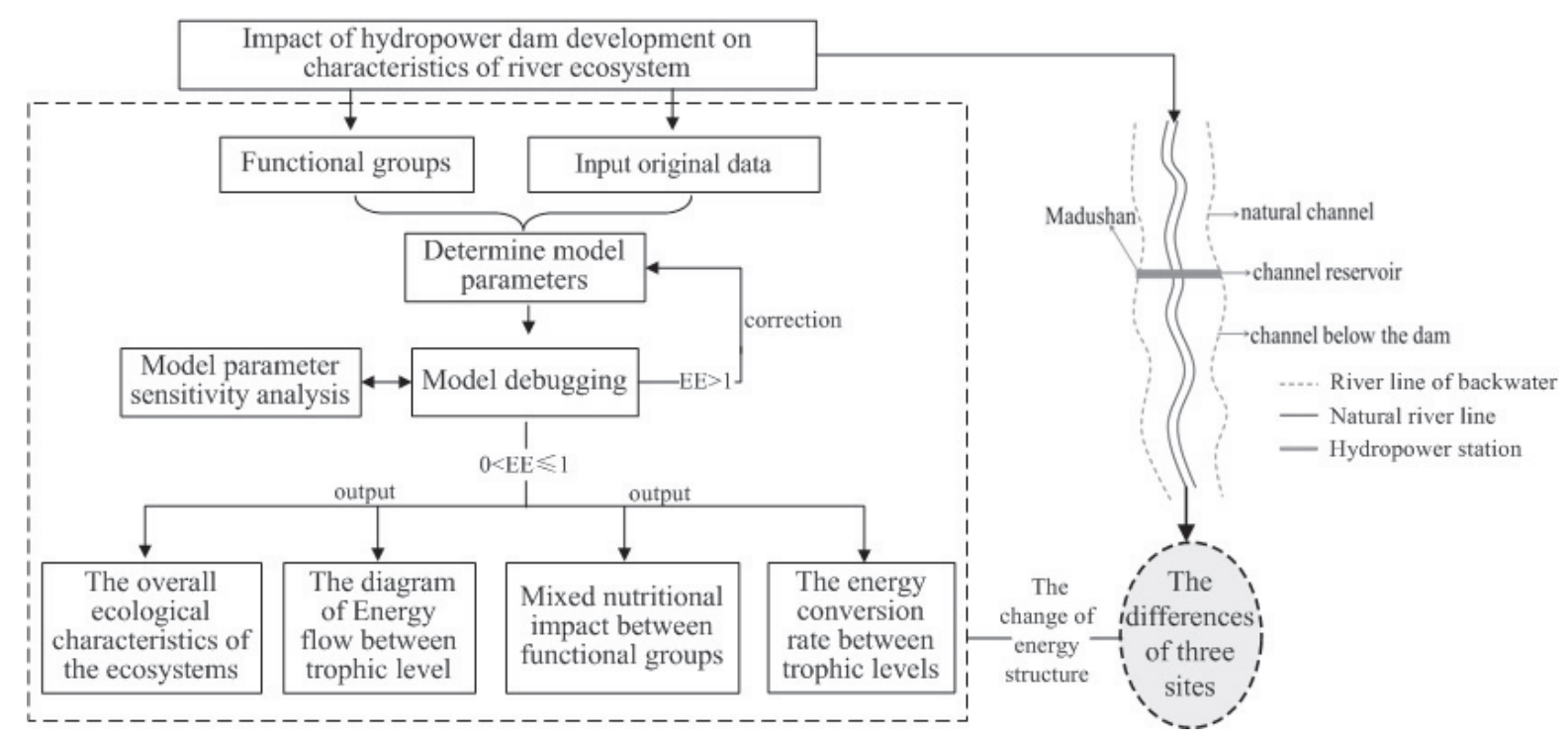

Fig. 2. Flow chart of the study. 


\section{Models and Data Sources}

\section{Introduction to Ecopath Model}

The Ecopath approach was derived from the original master Ecopath proposed by Polovina to describe energy flow between species in aquatic ecosystem biomass estimates and food consumption relationships [24]. Then further extended and improved to a user-friendly software package for personal computers through the inclusion of extensive routine implementing ecological theory [25]. The model assumes mass-balance between groups, and their interactions are described by linear equations. For each compartment (i), a mass-balance budget can be expressed as:

$$
P_{i}=Y_{i}+B_{i} M 2_{i}+E_{i}+B A_{i}+P_{i}\left(1-E E_{i}\right)
$$

... where $P_{i}$ is the total production rate of group $i, Y_{i}$ is the total fishery catch rate of group $I, B i$ is biomass of $i, M 2_{i}$ is the total predation rate for $i, E_{i}$ is the net migration (emigration-immigration), $B A_{i}$ is the biomass accumulation rate for $i, E E_{i}$ is the ecotrophic efficiency of group $i, 1-E E_{i}$ is the proportion of $P_{i}$ that is not consumed by predators included in the model, nor caught by the fishery, nor accumulated in the system.

The energy transfer equations can be expressed as follows:

$$
B_{i} \times(P / B)_{i} \times E E i-\sum_{j}^{n} B_{j} \times(Q / B)_{j} \times D C_{j i}-E X_{i}=0
$$

...where subscript $i$ refers to the prey group and $j$ is defined as predators, $B_{i}=$ initial biomass of the prey group, $(P / B)_{i}=$ production /biomass ratio of group, $(Q / B)_{i}=$ food consumption/biomass ratio of predator, $E X_{i}=$ the net migration rate (emigration-immigration), and $D C_{j i}=$ the contribution of prey $i$ in the diet of predator $j$.

\section{Divisions of Functional Groups}

Divisions of functional groups in the Ecopath model are mainly based on the requirements of the whole system and the relevant ecological theories [26], and combine species with high overlap of ecological niches (food composition, feeding patterns, individual size, age composition, etc.) to simplify the food web. In general, functional groups in the Ecopath model can be divided in accordance with the following principles [27]:

1. At least one detritus group is needed in the functional group divisions.

2. Species with the same or similar ecological niches are divided into the same functional group instead of using the traditional biological taxonomic methods to carry out the divisions.
Table 1. Functional group parameters of Ecopath model of NC.

\begin{tabular}{|c|c|c|c|c|}
\hline Functional Groups & $\begin{array}{c}B \\
\left(\mathrm{t} / \mathrm{km}^{2}\right)\end{array}$ & $\begin{array}{c}P / B \\
\left(\mathrm{year}^{-1}\right)\end{array}$ & $\begin{array}{c}Q / B \\
\left(\text { year }^{-1}\right)\end{array}$ & $E E$ \\
\hline Channa gachua & 1.12 & 1.03 & 11.4 & 0.003 \\
\hline $\begin{array}{c}\text { Cyprinus } \\
\text { rubrofuscus }\end{array}$ & 6.7 & 0.92 & 10.4 & 0.849 \\
\hline Sisoridae & 3.76 & 0.85 & 12.7 & 0.814 \\
\hline Abbottina rivularis & 0.83 & 1.1 & 8.5 & 0.801 \\
\hline $\begin{array}{c}\text { Opsariichthys } \\
\text { bidens }\end{array}$ & 1.6 & 1.03 & 8.7 & 0.655 \\
\hline Other small fishes & 1.63 & 2.57 & 13.5 & 0.918 \\
\hline Schistura fasciolata & 23.6 & 1.81 & 10.8 & 0.928 \\
\hline Balitoridae & 5.2 & 1.94 & 12 & 0.837 \\
\hline Rotifer & 0.96 & 20 & 120 & 0.635 \\
\hline Protozoon & 0.1 & 20 & 120 & 0.831 \\
\hline Arthropod & 2.9 & 3 & 20 & 0.872 \\
\hline Mollusc & 17 & 3 & 20 & 0.862 \\
\hline Phytoplankton & 14.2 & 60 & - & 0.506 \\
\hline Detritus & 18.9 & - & - & 0.472 \\
\hline
\end{tabular}

\begin{tabular}{|c|c|c|c|c|}
\hline Functional Groups & $\begin{array}{c}B \\
\left(\mathrm{t} / \mathrm{km}^{2}\right)\end{array}$ & $\begin{array}{c}P / B \\
\left(\text { year }^{-1}\right)\end{array}$ & $\begin{array}{c}Q / B \\
\left(\text { year }^{-1}\right)\end{array}$ & $E E$ \\
\hline $\begin{array}{l}\text { Cultrichthys } \\
\text { erythropterus }\end{array}$ & 0.04 & 5.34 & 7.7 & 0.005 \\
\hline $\begin{array}{l}\text { Hemibagrus } \\
\text { pluriradiatus }\end{array}$ & 0.12 & 0.75 & 11.5 & 0.958 \\
\hline $\begin{array}{l}\text { Cyprinus } \\
\text { rubrofuscus }\end{array}$ & 0.09 & 0.87 & 10.4 & 0.845 \\
\hline $\begin{array}{l}\text { Opsariichthys } \\
\text { bidens }\end{array}$ & 0.06 & 1.49 & 8.7 & 0.808 \\
\hline Other small fishes & 0.02 & 1.44 & 13.5 & 0.907 \\
\hline $\begin{array}{l}\text { Rhinogobius } \\
\text { honghensis }\end{array}$ & 0.05 & 2.35 & 11.7 & 0.774 \\
\hline $\begin{array}{c}\text { Rhenogobius } \\
\text { brunneus }\end{array}$ & 0.07 & 1.8 & 12.7 & 0.928 \\
\hline Nemacheilidae & 0.22 & 2.29 & 10.8 & 0.749 \\
\hline $\begin{array}{c}\text { Ctenopharyngodon } \\
\text { idella }\end{array}$ & 0.058 & 4.07 & 6.3 & 0.626 \\
\hline Rotifer & 0.32 & 20 & 120 & 0.622 \\
\hline Copepoda & 31.03 & 20 & 120 & 0.507 \\
\hline Cladocera & 14.19 & 20 & 120 & 0.792 \\
\hline Protozoon & 0.02 & 20 & 120 & 0.832 \\
\hline Arthropod & 0.7 & 3 & 20 & 0.303 \\
\hline Mollusc & 7 & 3 & 20 & 0.442 \\
\hline Phytoplankton & 63 & 60 & - & 0.632 \\
\hline Detritus & 9 & - & - & 0.900 \\
\hline
\end{tabular}

Table 2. Functional group parameters of Ecopath model of CR. 
Table 3. Functional group parameters of Ecopath model of CB.

\begin{tabular}{|c|c|c|c|c|}
\hline Functional Groups & $\begin{array}{c}B \\
\left(\mathrm{t} / \mathrm{km}^{2}\right)\end{array}$ & $\begin{array}{c}P / B \\
\left(\mathrm{year}^{-1}\right)\end{array}$ & $\begin{array}{c}Q / B \\
\left(\mathrm{year}^{-1}\right)\end{array}$ & $E E$ \\
\hline $\begin{array}{c}\text { Gobiobotia } \\
\text { yuanjiangensis }\end{array}$ & 0.06 & 2.68 & 16.7 & 0.002 \\
\hline Sisoridae & 0.19 & 0.87 & 12 & 0.849 \\
\hline Other small fishes & 0.15 & 2.31 & 19.4 & 0.814 \\
\hline $\begin{array}{c}\text { Opsariichthys bidens } \\
\text { Rhenogobius } \\
\text { brunneus }\end{array}$ & 1.21 & 3.24 & 8.7 & 0.801 \\
\hline $\begin{array}{c}\text { Rhinogobius } \\
\text { honghensis }\end{array}$ & 0.18 & 2.36 & 11.5 & 0.918 \\
\hline Schistura fasciolata & 0.62 & 1.62 & 10.8 & 0.928 \\
\hline Balitoridae & 0.19 & 1.72 & 12 & 0.837 \\
\hline Rotifer & 4.44 & 20 & 120 & 0.635 \\
\hline Protozoon & 0.035 & 20 & 120 & 0.831 \\
\hline Arthropod & 0.7 & 3 & 20 & 0.872 \\
\hline Mollusc & 7 & 3 & 20 & 0.862 \\
\hline Phytoplankton & 30.7 & 60 & - & 0.506 \\
\hline Detritus & 20.2 & - & - & 0.471 \\
\hline
\end{tabular}

3. the divided functional groups can basically cover the whole process of energy flows in the studied ecosystems; the functional groups of dominant species and key species are particularly indispensable.

According to the above principles, the Ecopath models of the three typical reaches of the Red River basin are divided into different functional groups based on the data obtained from the related investigation. There are, respectively, 14, 17, and 14 functional groups in NC, $\mathrm{CR}$, and $\mathrm{CB}$, and these functional groups basically cover the whole process of bio-energy flows in the three water ecosystems.

\section{Data and Parameter Estimation}

In this paper, the flow unit of energy in the Ecopath model in the system is biomass in $t \cdot \mathrm{km}^{-2} \cdot \mathrm{y}^{-1}$. The biomass data of phytoplankton, zooplankton, zoobenthos, and important fish resources in the Red River basin mainly come from a 2011-13 survey data. According to the topographic feature, property of the aquatic organisms and hydrologic characteristics of the Red River, 25 sampling points have been successively set (respectively 10,7 , and 8 sampling points in $\mathrm{NC}, \mathrm{CR}$, and $\mathrm{CB}$ ). In the annual dry and rainy seasons the samples of the phytoplankton, zooplankton, zoobenthos, and fish are collected and analyzed qualitatively and quantitatively by the research group based on the Handbook of Natural Fishery Resources Survey in Inland Waters [28]. The P/B and Q/B of the fish functional group are calculated by querying the fishery database website (fishbase.org), and the biomass of detritus is estimated by referring to the linear model proposed by Pauly et al. [29]. The P/B values of phytoplankton and zooplankton are, respectively, set as 60 and 20 through consulting Xiao Yunjun and Song Bing's research [30-31]. Determining the proportion of nonassimilated food refers to a study of Liu et al. [32]. The diet composition (DC) of zooplanktons and zoobenthos is calculated by referring to the research data of Burn and Geller [33-34], whereas the DC of the fish is obtained through analysis of stomach contents. The obtained data are in accordance with the basic requirements for establishing the Ecopath model.

\section{Balancing the Model}

The Ecopath model needs to have the equation to achieve material and energy balance, and the balance of the model should meet the basic condition, namely $0<\mathrm{EE} \leq 1$. After the model is initialized by inputting parameters, the EE value may be greater than 1, and the EE values of all the functional groups can be in a reasonable range

Table 4. Transfer efficiencies of individual trophic levels in NC, CR, and CB.

\begin{tabular}{|c|c|c|c|c|c|c|c|c|c|c|c|c|c|c|c|}
\hline \multirow{2}{*}{$\begin{array}{c}\text { Soure/ } \\
\text { Trophic level }\end{array}$} & \multicolumn{4}{|c|}{$\mathrm{NC}$} & \multicolumn{6}{|c|}{$\mathrm{CR}$} & \multicolumn{5}{|c|}{$\mathrm{CB}$} \\
\hline & II & III & IV & V & II & III & IV & V & VI & VII & II & III & IV & V & VI \\
\hline Producer & 13.2 & 7.2 & 2.2 & 0.2 & 2.3 & 1.6 & 9.1 & 5.1 & 1.8 & - & 4.9 & 19.6 & 15.9 & 1.9 & - \\
\hline Detritus & 13.3 & 7.4 & 2.5 & 0.2 & 1.9 & 2.5 & 9.7 & 5.7 & 1.9 & - & 5.0 & 19.5 & 16.8 & 2 & - \\
\hline All flows & 13.3 & 7.3 & 2.3 & 0.2 & 2.1 & 2.1 & 9.5 & 5.5 & 1.9 & 0.2 & 5.0 & 19.5 & 16.3 & 1.9 & 0.6 \\
\hline PTFOFD $^{1}$ & \multicolumn{4}{|c|}{0.53} & \multicolumn{6}{|c|}{0.53} & \multicolumn{5}{|c|}{0.52} \\
\hline TEFPP $^{2}$ & \multicolumn{4}{|c|}{$5.9 \%$} & \multicolumn{6}{|c|}{$3.2 \%$} & \multicolumn{5}{|c|}{$11.5 \%$} \\
\hline TEFD $^{3}$ & \multicolumn{4}{|c|}{$6.2 \%$} & \multicolumn{6}{|c|}{$3.6 \%$} & \multicolumn{5}{|c|}{$11.8 \%$} \\
\hline Total & \multicolumn{4}{|c|}{$6.1 \%$} & \multicolumn{6}{|c|}{$3.5 \%$} & \multicolumn{5}{|c|}{$11.6 \%$} \\
\hline
\end{tabular}

\footnotetext{
${ }^{1}$ Proportion of total flow originating from detritus;

${ }^{2}$ Transfer efficiency from primary producers;

${ }^{3}$ Transfer efficiency from detritus
} 
by adjusting DC and the relevant input parameters so as to output the overall characteristics of the ecosystem and other parameter values [35]. Through the entering of the functional group parameters and the debugging of the model, the input and output results of the Ecopath model of the ecosystems of NC, CR, and CB are shown in Tables 1,2 , and 3 .

\section{Network Analysis and Ecosystem Properties}

In the Ecopath model all ecological groups were also assigned discrete trophic levels according to Lindeman with the approach suggested by Ulanowicz [36]. Then, a modified input-output analysis with the mixed trophic impacts (MTI) procedure described by Ulanowicz and Puccia was implemented in the EwE [37]. The MTI model is used to reflect the (positive and negative) effects of interactions among various functional groups, whereas the values are between -1 and +1 , and specifically the positive effect should take the positive value while the negative effect should take the negative value. MTI also considers the direct and indirect effects among functional groups, and is used to assess the influence of changes in the biomass of a certain functional group on other functional

a)
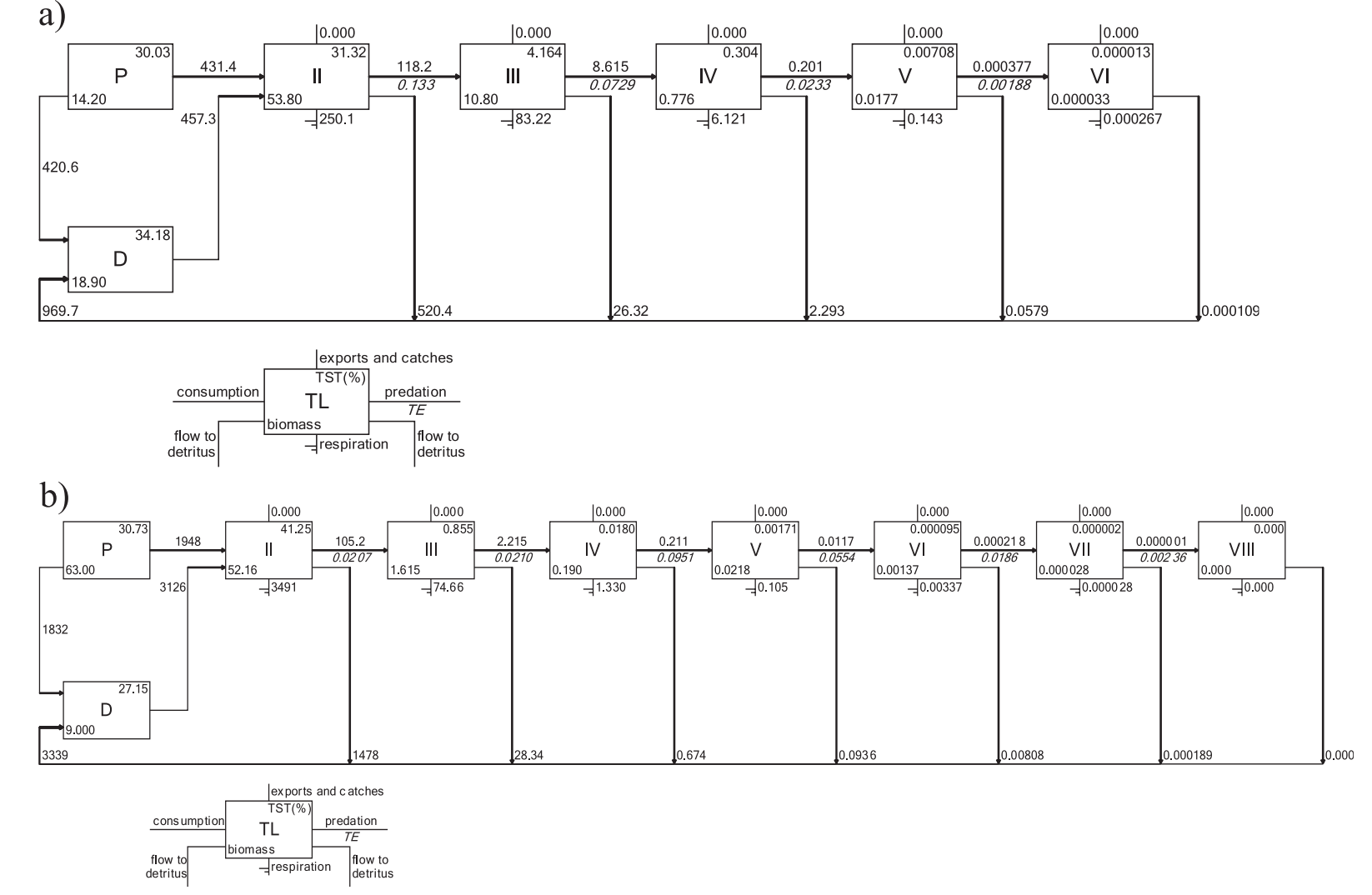

c)
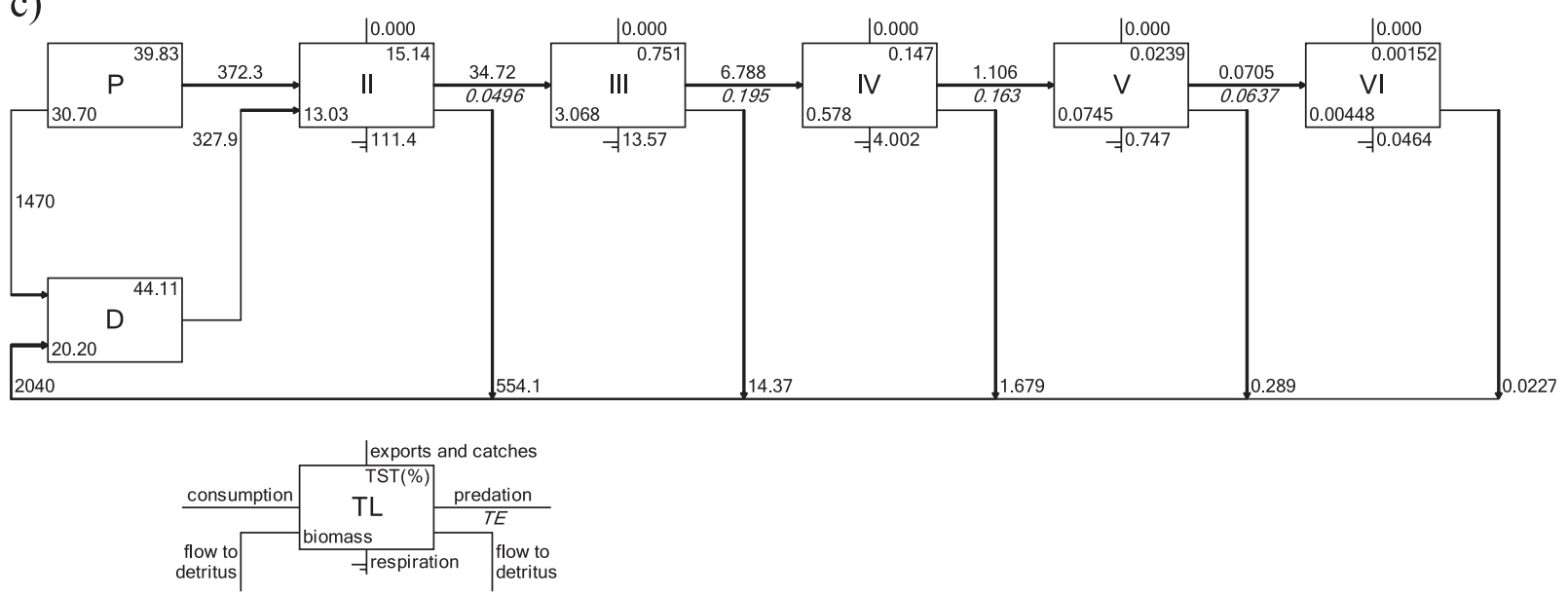

Fig. 3. Lindeman spine of the three different ecosystems: a) NC, b) CR, c) CB.P, and D represent the primary production and detritus, respectively, while the values in boxes indicate the biomass and percentage of total system throughput (TST) for each trophic level (TL). The values above and below arrows exhibit the efficiency of energy transfer (TE) through each trophic level. 
groups in the model through the comprehensive analysis of the food webs [38]. If the block diagram is larger, it indicates that the impact on the functional group is greater.

Theoretically, in EwE the ecosystem properties were quantified by implementing the ecosystem theories by scholars. Sequentially, a set of indicators were used to describe and assess the stability and maturity of the ecosystem [35]. The ratio total primary production/total respiration (TPP/TR) is an indicator of the maturity of ecosystem where mature systems have a ratio of 1 . The total biomass/total throughput ratio (B/TT) describes the total biomass relative to the available energy in the system, and is expected to increase with ecosystem maturity. The connectance index $(\mathrm{CI})$ and the system omnivory index (SOI) are the indicators reflecting the complexity of the internal links of the system. Finn's cycling index (FCI) and Finn's mean path length (FML) indicated the degree of recycling in the ecosystem [39].

\section{Results and Discussion}

\section{Comparing Transfer Efficiencies of Various Trophic Levels in Different River Ecosystems}

As can be seen from Table 4, the energy flows mainly between trophic levels I and IV in the $\mathrm{NC}, \mathrm{CR}$, and $\mathrm{CB}$ ecosystems. In the NC ecosystem the total flow transfer efficiency of trophic level $\mathrm{I} \rightarrow \mathrm{II}$ is the highest, reaching $13.3 \%$; in the CR ecosystem the highest value of the total flow transfer efficiency focuses on trophic level III $\rightarrow \mathrm{IV}$, reaching $9.5 \%$; and in the $\mathrm{CB}$ ecosystem the total flow transfer efficiencies of trophic level II $\rightarrow$ III and trophic level III $\rightarrow \mathrm{IV}$ are higher, reaching $19.5 \%$ and $16.3 \%$, respectively. The overall transfer efficiencies of the three ecosystems are characterized by $\mathrm{CR}<\mathrm{NC}<\mathrm{CB}$, and the values are $3.5 \%, 6.1 \%$, and $11.6 \%$, respectively, while the transfer efficiencies of the detritus also show the same rule, and the values are, respectively, $3.6 \%, 6.2 \%$, and $11.8 \%$.

\section{Comparisons of Material Flows of Various Trophic Levels in Different River Ecosystems}

Fig. 3 shows that in the three ecosystems of $\mathrm{NC}, \mathrm{CR}$, and $\mathrm{CB}$, the productions of primary producers are characterized by $\mathrm{CR}>\mathrm{CB}>\mathrm{NC}$, and the values are respectively $852 \mathrm{t} \cdot \mathrm{km}^{-2} \cdot \mathrm{y}^{-1}, 3,780 \mathrm{t} \cdot \mathrm{km}^{-2} \cdot \mathrm{y}^{-1}$, and $1,842.3 \mathrm{t} \cdot \mathrm{km}^{-2} \cdot \mathrm{y}^{-1}$. Among them, the recycling flows into the detritus are, respectively, $420.6 \mathrm{t} \cdot \mathrm{km}^{-2} \cdot \mathrm{y}^{-1}$, $1,832 \mathrm{t} \cdot \mathrm{km}^{-2} \cdot \mathrm{y}^{-1}$, and $1,470 \mathrm{t} \cdot \mathrm{km}^{-2} \cdot \mathrm{y}^{-1}$, accounting for $49.37 \%, 48.46 \%$, and $79.79 \%$ of the primary production in the three ecosystems of $\mathrm{NC}, \mathrm{CR}$, and $\mathrm{CB}$. However, the flows into each trophic level II from the output of primary producers in the three ecosystems of $\mathrm{NC}, \mathrm{CR}$, and $\mathrm{CB}$ respectively account for $48.54 \%, 38.39 \%$, and $53.17 \%$ of the total flow into each trophic level II, and the rest of the inflows are all from organic detritus. This shows the importance of the detrital food chain in energy flows in river ecosystems - especially for CR. The total flows into detritus from various trophic levels are $969.7 \mathrm{t} \cdot \mathrm{km}^{-2} \cdot \mathrm{y}^{-1}, 3,339 \mathrm{t} \cdot \mathrm{km}^{-2} \cdot \mathrm{y}^{-1}$, and 2,040 $\mathrm{t} \cdot \mathrm{km}^{-2} \cdot \mathrm{y}^{-1}$, exceeding the outputs of primary producers (except in the ecosystem of $\mathrm{CB}$ ). The amounts of feeding by the detritus group are $457.3 \mathrm{t} \cdot \mathrm{km}^{-2} \cdot \mathrm{y}^{-1}, 2,685 \mathrm{t} \cdot \mathrm{km}^{-2} \cdot \mathrm{y}^{-1}$, and $327.9 \mathrm{t} \cdot \mathrm{km}^{-2} \cdot \mathrm{y}^{-1}$, while the remaining part is deposited by the impact of mineralization.

\section{Energy Flow Relationship of Various Functional Groups in Different River Ecosystems}

Trophic flows directly affect the static structure, fundamental function, substance circulation, and information transfer in this ecological system. The balanced network flow diagram is presented in Fig. 4, showing the correlation between biomass, energy flow, and consumption, and the range of biomass flows between

a)

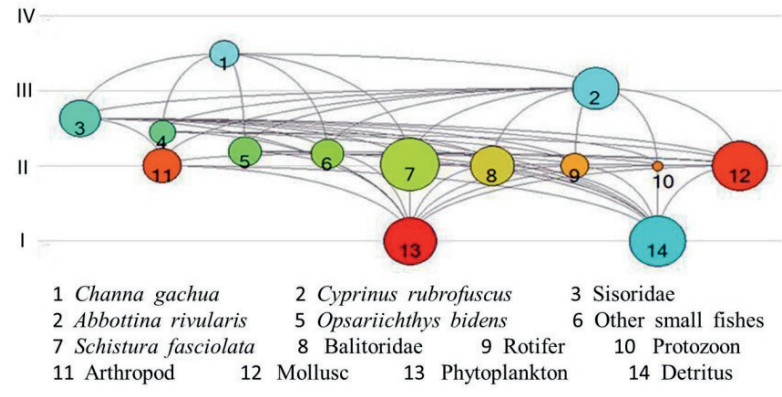

b)

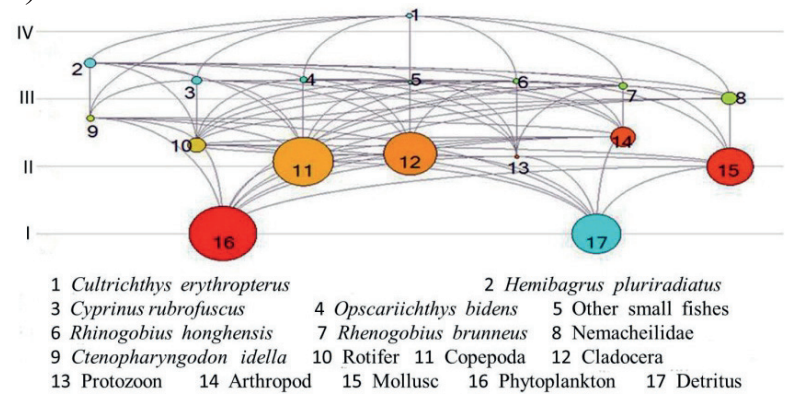

c)

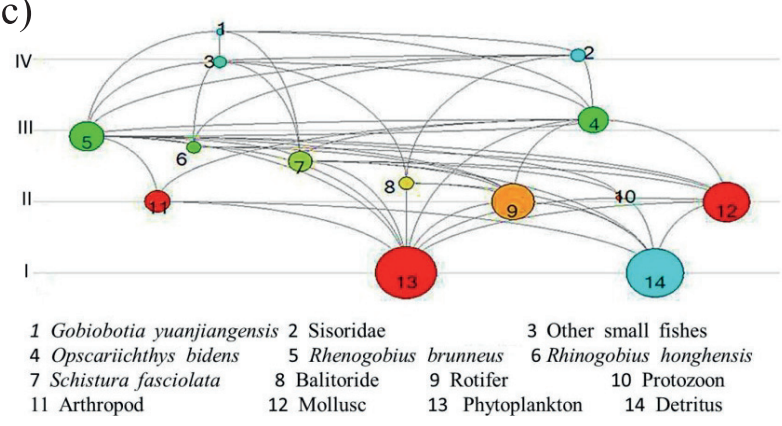

Fig. 4. Schematic diagram of energy flow represented the food web structure of the three different ecosystems: a) NC, b) CR, and c) CB. The grey lines denote trophic levels I, II, III, and $\mathrm{IV}$, while the different sizes of the circles indicate the different biomasses $\left(\mathrm{t} \mathrm{km}^{-2}\right)$ of the functional groups. 
a)

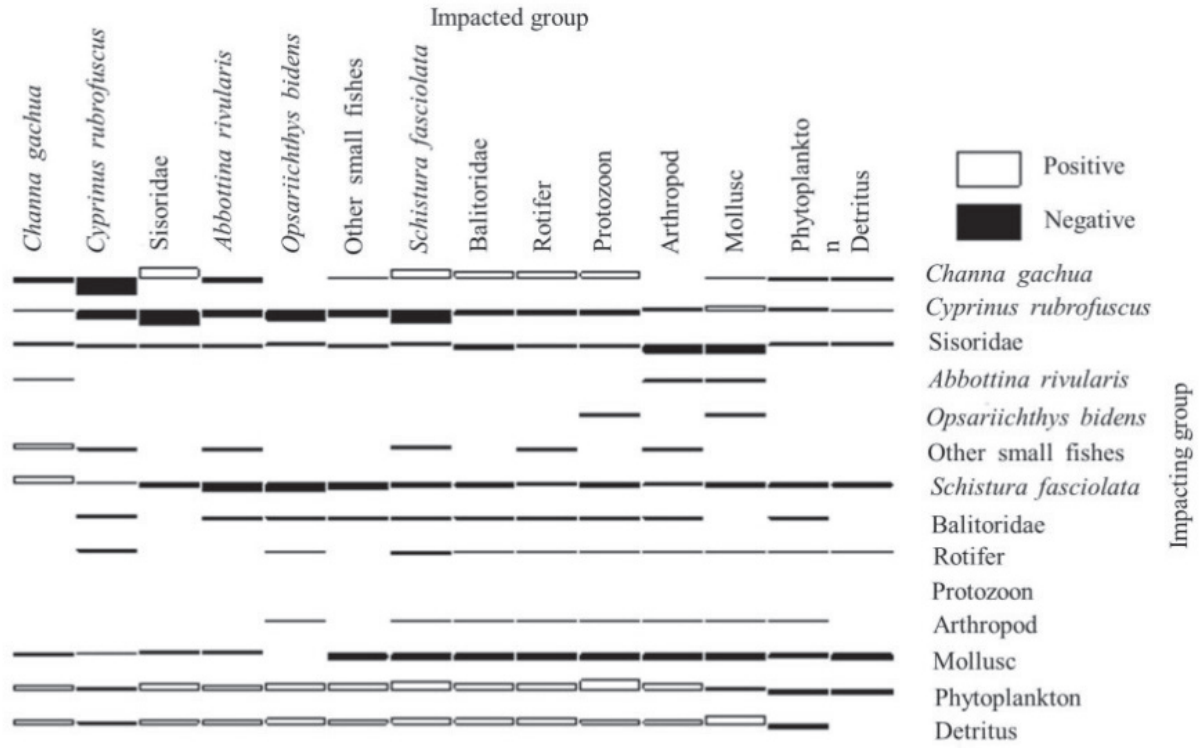

b)

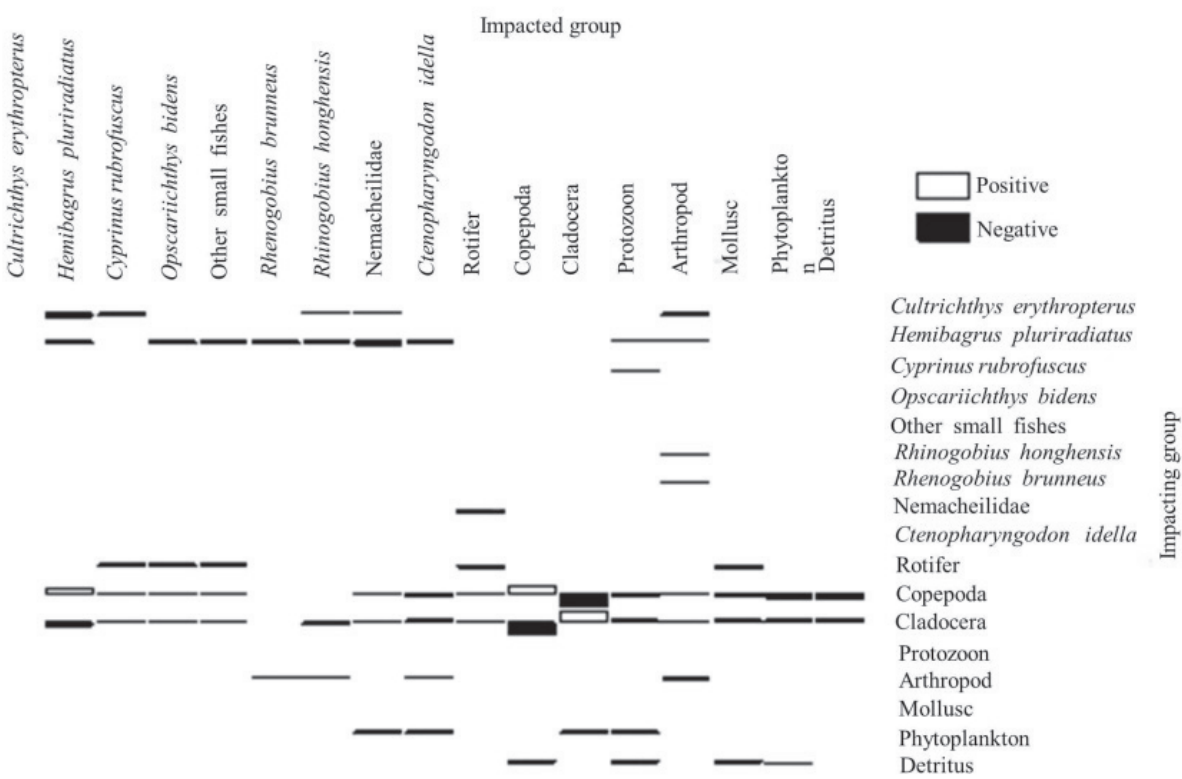

c)
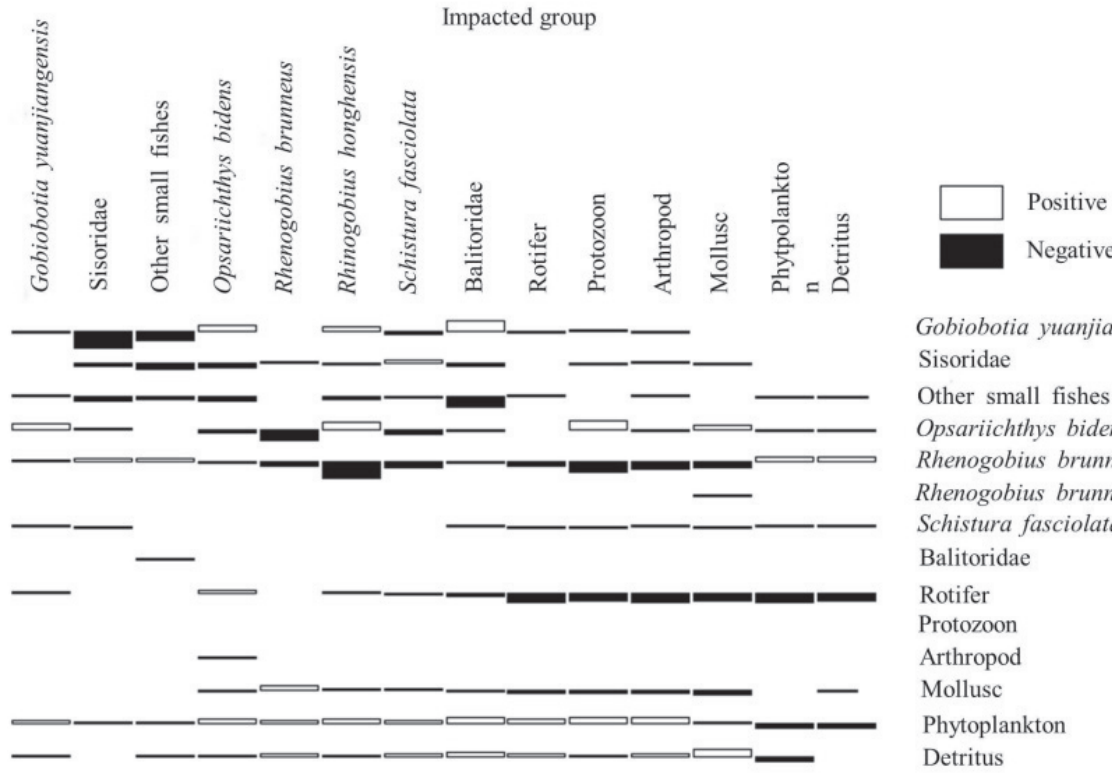

Gobiobotia yuanjiangensis Sisoridae

Other small fishes Opsariichthys bidens Rhenogobius brunneus Rhenogobius brunneus Schistura fasciolata Balitoridae

Rotife

Protozoon

Arthropod

Mollusc

Phytoplankton

Detritus

Fig. 5. Mixed trophic impact (MTI) of the three different ecosystems: a) NC, b) CR, and c) CB. 
Table 5. Summary of system statistics obtained for the NC, CR, and CB ecosystems from Ecopath.

\begin{tabular}{|c|c|c|c|c|}
\hline \multirow{2}{*}{ System index } & & value & & \multirow{2}{*}{ Units } \\
\hline & $\mathrm{NC}$ & $\mathrm{CR}$ & $\mathrm{CB}$ & \\
\hline Total consumption (TC) & $1,015.660$ & $5,628.832$ & 743.911 & $\mathrm{t} \cdot \mathrm{km}^{-2} \cdot \mathrm{y}^{-1}$ \\
\hline Total exports (TEX) & 512.408 & 212.719 & $1,712.248$ & $\mathrm{t} \cdot \mathrm{km}^{-2} \cdot \mathrm{y}^{-1}$ \\
\hline Total respiratory flows (TR) & 339.592 & $3,567.282$ & 129.752 & $\mathrm{t} \cdot \mathrm{km}^{-2} \cdot \mathrm{y}^{-1}$ \\
\hline Total flows into detritus (TDET) & 969.705 & $2,897.749$ & $2,040.139$ & $\mathrm{t} \cdot \mathrm{km}^{-2} \cdot \mathrm{y}^{-1}$ \\
\hline Total system throughput $(\mathrm{T})$ & $2,837.365$ & $12,306.580$ & $4,626.050$ & $\mathrm{t} \cdot \mathrm{km}^{-2} \cdot \mathrm{y}^{-1}$ \\
\hline Total production (TP) & $1,002.968$ & $4,715.783$ & $1,967.127$ & $\mathrm{t} \cdot \mathrm{km}^{-2} \cdot \mathrm{y}^{-1}$ \\
\hline Calculated total net primary production (TPP) & 852.000 & $3,780.000$ & $1,842.000$ & $\mathrm{t} \cdot \mathrm{km}^{-2} \cdot \mathrm{y}^{-1}$ \\
\hline Total primary production/total respiration (TPP/TR) & 2.509 & 1.060 & 14.196 & - \\
\hline Net system production (NSP) & 512.408 & 212.718 & $1,712.248$ & $\mathrm{t} \cdot \mathrm{km}^{-2} \cdot \mathrm{y}^{-1}$ \\
\hline Total primary production/total biomass (TPP/TB) & 10.704 & 32.311 & 38.816 & - \\
\hline Total biomass/total throughput (B/TT) & 0.028 & 0.010 & 0.010 & - \\
\hline Total biomass (excluding detritus) & 79.600 & 116.988 & 47.455 & $\mathrm{t} \cdot \mathrm{km}^{-2}$ \\
\hline Connectance index (CI) & 0.301 & 0.308 & 0.290 & - \\
\hline System omnivory index (SOI) & 0.043 & 0.140 & 0.086 & - \\
\hline Finn's cycling index (FCI) & 13.700 & 15.060 & 7.070 & $\%$ \\
\hline Finn's mean path length (FML) & 3.330 & 3.256 & 2.511 & - \\
\hline
\end{tabular}

functional groups and trophic levels. There are four trophic levels in the Ecopath model, and some trophic energy is utilized in respiration at each trophic level. Moreover, the results indicate that there are grazing food chains and detrital food chains in energy flows of the three sites. For instance, in $\mathrm{NC}$ the grazing food chain is: phytoplankton - arthropod - Abbottina rivularis - Channa gachua, and the detrital food chain is: detritus - rotifer - Cyprinus rubrofuscus. There are similar food chains in CR, namely phytoplankton - rotifer - Cyprinus rubrofuscus - Cultrichthys erythropterus and detritus - arthropod - Rhenogobius brunneus - Cultrichtys erythropterus. Similarly, the food chains in CB are phytoplankton Schistura fasciolata - Gobiobotia yuanjiangensis and detritus - rotifer - Opsariichthys bidens - Sisorodae.

\section{Trophic Relationships of the NC, CR, and $\mathrm{CB}$ Ecosystems}

Mixed trophic impacts (MTI) are shown in Fig. 5, which shows that in the NC ecosystem, detritus and phytoplankton have a positive effect on most fish (except Cyprinus rubrofuscus), Protozoon, arthropod, mollusc, and low-level fish have a negative impact on each other due to food competition. Affected by the dual role of primary producers and top predators, Schistura fasciolata, Cyprinus rubrofuscus, and Sisoridae have a strong influence on the energy flows of the system, and play a key role in the effective transfer of energy. In the ecosystem of $\mathrm{CR}$, interactions among various functional groups are weaker, and Cladocera, Copepoda, and Hemibagrus pluriradiatus have a strong impact on the energy flows of the system, having a negative effect on most functional groups, while there are significant positive effects between Cladocera and Copepoda. In the ecosystem of $\mathrm{CB}$, phytoplankton has a positive influence on most fish (except Cyprinus rubrofuscus), protozoon, arthropod, and mollusc, whereas detritus has a negative effect on most fish. There are obvious predation and competition relationships among the fish, and in particular, Rhenogobius brunneus and Gobiobotia yuanjiangensis have a marked negative impact on Rhenogobius honghensis and Sisoridae, while Rhenogobius brunneus, rotifer and sisoridae have a strong positive effect on the energy flows of the system, having a negative influence on most functional groups.

\section{Comparisons of the Overall Characteristics of Different River Ecosystems}

The Ecopath model provides a lot of indicators in Table 5 that are used to determine the size, stability, maturity, and other overall system characteristics of the ecosystem.

The total ecosystem flows include four components: total consumption (TC), total exports (TEX), total respiratory flows (TR), and total flows into detritus (TDET). The total flows of the ecosystems of $\mathrm{NC}, \mathrm{CR}$, and $\mathrm{CB}$ are characterized by $\mathrm{CR}>\mathrm{CB}>\mathrm{NC}$, and the values are $12,306.580 \mathrm{t} \cdot \mathrm{km}^{-2} \cdot \mathrm{y}^{-1}, 4,626.050 \mathrm{t} \cdot \mathrm{km}^{-2} \cdot \mathrm{y}^{-1}$, and $2,837.365 \mathrm{t} \cdot \mathrm{km}^{-2} \cdot \mathrm{y}^{-1}$, respectively. 
TPP/TR is an important parameter used to characterize the mature state of the ecosystem, and the TPP/TR value of the mature ecosystem is close to 1 . The TPP/TR value of the ecosystem of $\mathrm{CB}$ is significantly higher than that of $\mathrm{NC}$ and CR, and the values are 14.196, 2.509 and 1.060, respectively. The results show that the ecosystems of $\mathrm{CR}$, $\mathrm{NC}$, and $\mathrm{CB}$ are, respectively, in the mature, immature, and unstable "young" state. In addition, the net system production (NSP) values of the ecosystems of $\mathrm{CB}, \mathrm{NC}$, and $\mathrm{CR}$ are $1,712.248 \mathrm{t} \cdot \mathrm{km}^{-2} \cdot \mathrm{y}^{-1}, 512.408 \mathrm{t} \cdot \mathrm{km}^{-2} \cdot \mathrm{y}^{-1}$, and $212.718 \mathrm{t} \cdot \mathrm{km}^{-2} \cdot \mathrm{y}^{-1}$, respectively. The NSP value of the ecosystem of $\mathrm{CB}$ is remarkably higher than that of $\mathrm{NC}$ and $\mathrm{CR}$, while the total biomass (excluding detritus) of the ecosystem of $\mathrm{CB}$ is obviously lower than that of $\mathrm{NC}$ and $\mathrm{CR}$, indicating that the ecosystem of $\mathrm{CB}$ is noticeably affected by the hydropower development.

$\mathrm{CI}$ and $\mathrm{SOI}$ are the indicators reflecting the complexity of the internal links of the system. If the system is more mature, the links (food webs) among various functional groups of the system will be more complex, so the values of CI and SOI are positively correlated with the maturity of the system [40-41]. The results indicate that CI and SOI of the ecosystem of $\mathrm{NC}$ are 0.301 and 0.043 , respectively, and those of CR are 0.308 and 0.140 , respectively, while those of CB are 0.290 and 0.086 , respectively. CI and SOI of the CR ecosystem are the highest, suggesting that the maturity and stability of the system are higher and the structures of food webs are relatively diverse.

Cycling flows refers to the total re-entering and recycling trophic flows in the system, and FCI indicates the ratio of the cycling flows to the total flows in the system, while FML denotes the mean length of each cycle flowing through the food chain [40-41]. One of the characteristics of the mature system is the higher proportion of the material recycling and the longer food chain where trophic flows pass. It is suggested from the research that FCI and FML of the ecosystem of CR are, respectively, $15.060 \%$ and $3.256 \%$, which are greater than those of $\mathrm{NC}$ and CB.

\section{Conclusion}

This paper uses the Ecopath model to carry out the comparison and analysis of the influences of a certain hydropower station on the ecosystems of $\mathrm{NC}, \mathrm{CR}$, and $\mathrm{CB}$ of the Red River. The results indicate that there are marked differences in the transformation efficiencies of various trophic levels, the material flows among various trophic levels, and the overall characteristics of ecosystems in the three ecosystems of $\mathrm{NC}, \mathrm{CR}$, and $\mathrm{CB}$. The overall transformation efficiencies are characterized by $\mathrm{CR}<\mathrm{NC}$ $<\mathrm{CB}$. From the perspective of the overall characteristics of the system, the TPP/TR value of the ecosystem of $\mathrm{CB}$ is 14.196, which is much greater than that of NC and CR. This indicates that the cascade hydropower development has changed the structure of the downstream ecosystem of the Red River and reduced the stability of the ecosystem. Besides, the NSP value of the ecosystem of $\mathrm{CB}$ is significantly higher than that of $\mathrm{NC}$ and $\mathrm{CR}$, while the total biomass (excluding detritus) of the ecosystem of $\mathrm{CB}$ is obviously lower than that of $\mathrm{NC}$ and $\mathrm{CR}$. The concern is that FCI and FML of the ecosystem of $\mathrm{CB}$ are markedly lower than those of $\mathrm{NC}$ and $\mathrm{CR}$, and the trophic interactions of the ecosystems are weakened, while the instability of the system is increased, so the phenomenon of retrogressive succession may occur in the ecosystem of CB.

In this study, the Ecopath model is used for the first time to evaluate the influences of the hydropower development on the structures and energy of the Red River ecosystems and indirectly characterize the discontinuity of the riverine ecology caused by dam-type hydropower development. Of course, there are still some deficiencies in this study, and the data is still rudimentary due to the limitation of the survey time and survey area. This is a common practice in the process of constructing the model, but the confidence level of the model in the specific waters will obviously be affected. Therefore, in future work, there may be a need to establish a long-term tracking mechanism and regularly obtain relevant data of different seasons and water levels. Meanwhile, research on the analysis of applied feeding habits of N, C, and other isotope techniques should be used to better improve the reliability of the model and data.

\section{Acknowledgements}

This study was funded by the National Natural Science Foundation of China (grant No. 41671016), the Open Research Fund of the State Key Laboratory of Simulation and Regulation of Water Cycle in River Basin, China Institute of Water Resources and Hydropower Research (grant No. IWHR-SKL-201509), and the Youth Innovation Promotion Associa-tion CAS (grant No. 2016332).

\section{References}

1. LIN B., WU Y., ZHANG, L. Electricity saving potential of the power generation industry in China. Energy, 40 (1), 307, 2012.

2. HONG L., ZHOU N., FRIDLEY D., RACZKOWSKI C. Assessment of China's renewable energy contribution during the12th Five Year Plan. Energy Policy, 62 (c), 1533, 2013.

3. CHENG C., LIU B., CHAU K.W., LI G., LIAO S. China's small hydropower and its dispatching management. Renewable \& Sustainable Energy Reviews, 42, 43, 2015.

4. ZENG M., LI C., ZHOU L. Progress and prospective on the police system of renewable energy in China. Renewable \& Sustainable Energy Reviews, 20 (4), 36, 2013.

5. ARDIZZON G., CAVAZZINI G., PAVESI G. A new generation of small hydro and pumped-hydropower plants: advances and future challenges. Renewable \& Sustainable Energy Reviews, 31 (2), 746, 2014.

6. KERM J.D., PATINO-ECHEVERRI D., CHARACKLIS G.W. An integrated reservoir-power system model for evaluating the impacts of wind integration on hydropower resources. Renew Energy, 71, 553, 2014.

7. HENNIG T., WANG W., FENG Y., QU X.K., HE D. Review of Yunnan's hydropower development. Comparing small and large hydropower projects regarding their environmental 
implications and socio-economic consequences. Renewable \& Sustainable Energy Reviews, 27, 585, 2013.

8. ANSAR A., FLYVNJERG B., BUDZIER A., LUNN D. Should we build more large dams? The actual costs of hydropower megaproject development. Energy Policy, 69 (6), 43-56, 2014.

9. ROSENBERG D.M., MCCULlY P., PRINGLE C.M. Global-scale environmental effects of hydrological alterations: introduction. BioScience, $\mathbf{5 0}$ (9), 746, 2000.

10. RENOFALT B.M., JANSSON R., NILSSON C. Effects of hydropower generation and opportunities for environmental flow management in Swedish riverine ecosystems. Freshwater Biology, 55 (1), 49, 2009.

11. ANDERSONE.P., PRINGLEC.M., ROJAS M. Transforming tropical rivers: an environmental perspective on hydropower development in Costa Rica. Aquatic Conservation Marine \& Freshwater Ecosystems, 16 (7), 679, 2010.

12. CHENG C., LIU B., CHAU K.W., LI G., LIAO S. China's small hydropower and its dispatching management. Renewable \& Sustainable Energy Reviews, 42, 43, 2015.

13. TOMBOLINI I., CANEVA G., CANCELLIERI L., ABATI S., CESCHIN S. Damming effects on upstream riparian and aquatic vegetation: the case study of Nazzano (Tiber River, central Italy). Knowledge \& Management of Aquatic Ecosystems, 24 (412), 350, 2014

14. CESCHIN S., TOMBOLINI I., ABATI S., ZUCCARELLO $\mathrm{V}$. The effect of river damming on vegetation: is it always unfavourable? A case study from the River Tiber (Italy). Environmental Monitoring \& Assessment, 187 (5), 301, 2015.

15. ABATI S., MINCIARDI M. R., CIADAMIDARO S., FATTORINI S., CESCHIN S. Response of macrophyte communities to flow regulation in mountain streams. Environmental Monitoring \& Assessment, 188 (7), 414, 2016,

16. ZHAI H., CUI B., HU B., ZHANG K. Prediction of river ecological integrity after cascade hydropower dam construction on the mainstream of rivers in Longitudinal Range-Gorge Region (LRGR), China. Ecological Engineering, 36 (4), 361, 2010.

17. KUMMU M., VARIS O. Sediment-related impacts due to upstream reservoir trapping, the Lower Mekong River. Geomorphology, 85 (3), 275, 2007.

18. ZHAI H. J., GUO L., SHI L. Regional ecosystem changes under different cascade hydropower dam construction scenarios in the LRGR. Science Bulletin, 52 (2), 106, 2007.

19. ROUSSEAU J. F. Does carbon finance make a sustainable difference? Hydropower expansion and livelihood trade - offs in the Red River valley, Yunnan Province, China. Singapore Journal of Tropical Geography, 38 (1), 90, 2017.

20. DE MUTSERT K., COWAN J.H. Jr., WALTERS C.J. Using Ecopath with Ecosim to Explore Nekton Community Response to Freshwater Diversion into a Louisiana Estuary. Marine \& Coastal Fisheries, 4 (1), 104, 2016.

21. COLLETER M., GASCUEL D., GUITTON J. An Introduction to the EcoTroph R Package: Analyzing Aquatic Ecosystem Trophic Networks. R Journal, 5 (1), 98, 2013.

22. STEENBEEK J., COLL M., GURNEY L., MELIN F., HOEPFFNER N., BUSZOWSKI J., CHRISTENSEN V. Bridging the gap between ecosystem modeling tools and geographic information systems: driving a food web model with external spatial-temporal data. Ecological Modelling, 263, 139, 2013.

23. HEYMANS J.J., COLL M., LINK J.S., MACKINSON S., STEEMBEEK J., WALTERS C., CHRISTENSEN V. Best practice in Ecopath with Ecosim food-web models for ecosystem-based management. Ecological Modelling, 331, 173, 2016.

24. POLOVINA J.J. Model of a coral reef ecosystem. Part I. Ecopath and its application to French Frigate Shoals. Coral Reefs, 3, 1, 1984.

25. FETAHI T, MENGISTOU S. Trophic analysis of Lake Awassa (Ethiopia) using mass-balance Ecopath model. Ecological Modelling, 201, 398, 2007.

26. CHOU Q.C., XU H.L., LIU J., SHI X.H. Construction of the EWE model of Futian mangrove wetland ecosystem. Chinese Journal of Ecology, 33 (5), 1413, 2014.

27. CHRISTENSEN V., WALTERS C.J. Ecopath with Ecosim: Methods, capabilities, and limitations. Ecological Modelling, 172, 109, 2004.

28. ZHANG J.M., HE Z.H. The Handbook of Natural Fishery Resources Survey in Inland Waters, China Agriculture Press: Beijing, China, 12, 1991 [In Chinese].

29. PAULY D., SORIANO-BARTZ M.L., PALOMARES M.L.D. Improved construction, parameterization and interpretation of steady-state ecosystem models. The Nineth Shrimp and Fin Fisheries Management Workshop, Kuwait, pp. 1, 1993.

30. YAN Y.J., LIANG Y.L. Energy flow of macrozoobenthic community in a macrophytic lake, Biandantang Lake. Acta Ecologia Sinica, 23, 527, 2003.

31. SONG B. Ecosystem modeling study on the fishery and environment of Taihu Lake. East China Normal University. Shanghai, pp. 38, 2004.

32. LIU Q.G., CHEN Y., LI J.L., CHEN L.Q. The food web structure and ecosystem properties of a filter-feeding carps dominated deep reservoir ecosystem. Ecological Modelling, 203 (3), 279, 2007

33. BURM C.W. Direct observation of mechanisms regulating feeding behavior of Daphnia in lake-water. International Review of Hydrobiology, 53, 83, 1968.

34. GELLER W., MULLER H. The filtration apparatus of Clado-cera: Filtermesh-sizes and their implications of food selectivity. Oncologia, 49 (3), 316, 1981.

35. CHRISTENSEN V., WALTERS C.J., PAULY D. Ecopath with Ecosim: A User's Guide. University of British Columbia, Fisheries Centre, Vancouver, Canada, 154, 2005.

36. CHEA R., GUO C., GRENOUILLET G., LEK S. Toward an ecological understanding of a flood-pulse system lake in a tropical ecosystem: Food web structure and ecosystem health. Ecological Modelling, 323, 1, 2016.

37. SELLESLAGH J., LOBRY J., AMARA R., BRYLINSKI J.M., BOET P. Trophic functioning of coastal ecosystems along an anthropogenic pressure gradient: A French case study with emphasis on a small and low impacted estuary. Estuarine Coastal \& Shelf Science, 112 (11), 73, 2012.

38. MORISSETTE L, BRODIE P.F. Assessing the trophic impacts of marine mammals: From metabolism to food web indices. Marine Mammal Science, 30 (3), 939, 2014.

39. JIA P, HU M, HU Z, WU Z. Modeling trophic structure and energy flows in a typical macrophyte dominated shallow lake using the mass balanced model. Ecological Modelling, 233 (2), 26, 2012.

40. DENG L., LIU S.L., DONG S.K., AN N.N., ZHAO H.D., LIU Q. Application of Ecopath model on trophic interactions and energy flows of impounded Manwan reservoir ecosystem in Lancang River, southwest China. Journal of Freshwater Ecology, 30 (2), 1, 2015.

41. XU S, CHEN Z, LI S, HE P. Modeling Trophic Structure and Energy Flows in a Coastal Artificial Ecosystem Using Mass-Balance Ecopath Model. Estuaries and Coasts, 34 (2), 351, 2011. 